\title{
EFFECT OF HUMIC SUBSTANCES AND WEATHER CONDITIONS ON LEAF BIOCHEMICAL CHANGES OF FERTIGATED GUAVA TREE, DURING ORCHARD ESTABLISHMENT ${ }^{1}$
}

\author{
BÁRBARA FRANÇA DANTAS², MAIANE SANTOS PEREIRA ${ }^{3}$, LUCIANA DE SÁ RIBEIRO ${ }^{4}$, \\ JOSELANNE LUIZA TRAJANO MAIA ${ }^{5}$, LUIS HENRIQUE BASSOI ${ }^{2}$
}

ABSTRACT - In São Francisco Valley, Northeast Brazil, humic substances have been used by growers in fertigated fruit crops, due to its improvements on soil conditions and in plant nutrient uptake, metabolism and growth, reported from different growing places and crops. Nevertheless, little information about plant response to humic substance usage for local soil, weather and cropping system conditions is known. Hence, the metabolic response of guava tree during the orchard establishment to fertigation with humic substances and its correlation to the weather conditions were evaluated in Petrolina, State of Pernambuco. The treatments were manure application in soil combined with mineral fertilizers and humic substances applied through irrigation water. The results showed that the fertigation treatments and plant age did not present conclusive effects in guava leaf contents of carbohydrates, proteins and amino acids. On the other side, the leaf contents of these compounds were influenced by the weather conditions.

Index terms: Psidium guajava, carbohydrates, proteins, amino acids

\section{EFEITO DE SUBSTÂNCIAS HÚMICAS E CONDIÇÕES METEOROLÓGICAS NAS ALTERAÇÕES BIOQUÍMICAS FOLIARES EM GOIABEIRAS FERTIRRIGADA, DURANTE A FORMAÇÃO DO POMAR}

RESUMO - No Vale do São Francisco, em Petrolina - PE, as substâncias húmicas têm sido aplicadas em fertirrigação de espécies frutíferas, baseando-se nas informações sobre melhorias que proporcionam ao solo, aumento de absorção de nutrientes, metabolismo e crescimento de plantas, obtidas em diferentes locais e culturas. Porém, existe pouca informação sobre as respostas das planta à aplicação de substâncias húmicas nas condições locais de solo, clima e sistema de cultivo. Assim, este trabalho avaliou a resposta metabólica de goiabeiras, em fase de formação, à fertirrigação com substâncias húmicas, e sua correlação com as condições climáticas em Petrolina - PE. Os tratamentos foram aplicação de esterco no solo combinada com a fertirrigação com fertilizantes minerais e com substâncias húmicas. Os tratamentos de fertirrigação e a idade das plantas não apresentaram resultados conclusivos quanto aos teores de carboidratos, proteínas e aminoácidos nas folhas de goiabeiras em formação. Por outro lado, os teores foliares dessas moléculas respondem às condições climáticas.

Termos para indexação: Psidium guajava, carboidratos, proteínas, aminoácidos.

\section{INTRODUCTION}

The São Francisco Valley, in the semi-arid region of Northeast Brazil, is characterized by low annual rainfall, high temperature and low relative air humidity. The guava tree under irrigation and pruning systems, have produced high yields (40 to 50 ton ha $^{-1}$ year $^{-1}$ ), in an intensive fruit cropping throughout the year, which provides guava fruits for in natura consumption and pulp for regional industries (Gonzaga Neto, 2001). In spite of the great economical importance of this fruit crop for this region, researches regarding to the physiological and metabolic behavior of guava trees are incipient.

The effects of humic substances on plant growth depend on the source and concentration (Kononova, 1982; Nardi et al., 2002), as well as on the molecular fraction weight of humus. Lower molecular size fraction easily reaches the plasmalemma of plant cells, determining a positive effect on plant growth, as well as a later effect at the level of plasma membrane, such as, the nutrient uptake, especially nitrate. The effects on intermediary metabolism are less understood, but it seems that humic substances may influence both respiration and photosynthesis (Nardi et al., 2002).

\footnotetext{
${ }^{1}$ (Paper 080-06). Received in:08-06-2006. Accepted for publication in : 10-08-2007. Research work financially supported by FACEPE, CNPq and Sustainable Agro Solutions S/A.

${ }^{2}$ Researcher, Dr, Embrapa Tropical Semi-Arid, P.O. Box 23, 56302-970, Petrolina - PE, Brazil barbara@cpatsa.embrapa.br, bassoi@cpatsa.embrapa.br

${ }^{3}$ Biologist, trainee, Embrapa Tropical Semi-ÁridoArid, Petrolina - PE, Brazil. lhbassoi@cpatsa.embrapa.br

${ }^{4}$ Biologist, Plant Physiology M.Sc. student, UENF, Av. Alberto Lamego, 2000, 28013-600, Campos dos Goytacazes, Campos - RJ, Brazil.

lusr@cpatsa.embrapa.br

${ }^{5}$ Agronomist, M.Sc., CNPq fellow, Embrapa Tropical Semi-Arid, Petrolina - PE, Brazil. ltmaia@uol.com.br
} 
Effects of humic substances on plants have been reported, i.e., stimulate growth and nutrient uptake in barley plants (Ayuso et al., 1996) and olive plants (Fernández-Escobar et al., 1996); enhance maize seed germination and growth (Eyheraguibel et al., 2004); increase dry weight of shoot, root growth, plant height and macronutrient uptake in oat plants (Rosa et al., 2004); enhance phosphorus uptake and dry matter production in corn (Andrade et al., 2004); increase grapevine berry diameter (Bassoi et al., 2005); increase leaf area and photosynthesis in cacao (Calima et al., 2005); stimulate growth and leaf $\mathrm{N}$ and chlorophyll content in wild olive (Murillo et al., 2005). Direct and indirect effects of humic substances on plant growth of a wide number of species are also presented by Chen \& Aviad (1990).

The mechanism by which humic and fulvic acids stimulate plant growth are not fully clear, although there are some theories which probably work together. Maggioni et al. (1987) indicated that humic and fulvic acids can influence the nutrient absorption, due to their effect on the $\mathrm{K}^{+}$and $\mathrm{Mg}^{2+}$ dependent ATPase. Pinton et al. (1992) demonstrated that the humic substances affect the activity of microssomal and tonoplast. Samson \& Visser (1989) demonstrated that cellular membrane permeability can be altered by these acids. These substances also present auxin and gibberellin-like effects on Raphanus sativus (Petrovic et al., 1982).

Enzymes and humic substances, when associated, can lead to the enhancement of activity of many enzymes (phosphorilase, phosphatase, cytochrome oxidase), to the inhibition of others (IAA oxidase, fitase, peroxidase), and to the synthesis of some (invertase) (Pospísil \& Hrubcova, 1974; Pereira \& Méndez, 1976; Vaughan \& Ord, 1980).

Nevertheless, there is no knowledge of these effects in guava plants grown in São Francisco Valley's weather and soil conditions, neither study of the plant metabolic responses. Hence, this study aimed to evaluate the biochemical behavior of guava trees to fertigation with humic substances during orchard establishment, and its correlation to weather conditions.

\section{MATERIAL AND METHODS}

The experiment was carried out at Bebedouro Experimental Field, Embrapa Tropical Semi-Arid, in Petrolina, State of Pernambuco, Brazil $\left(09^{\circ} 09^{\prime} \mathrm{S}, 42^{\circ} 22^{\prime} \mathrm{W}\right)$. At this site, an automatic weather station collected air temperature $\left({ }^{\circ} \mathrm{C}\right)$, insolation $\left(\mathrm{h} \mathrm{day}^{-1}\right)$ and global solar radiation ( $\mathrm{cal} \mathrm{cm}^{-1} \mathrm{day}^{-1}$ ) throughout the trial. Seedlings of guava cv. Paluma, 3 months old, were planted in May 2003 in a Yellow Red Latosol, medium texture, in $6 \times 5 \mathrm{~m}$ grid spacing. Plants were irrigated by micro sprinklers, with fertilizer application through irrigation water on a weekly basis. Before planting, $59 \mathrm{~g} \mathrm{P}_{2} \mathrm{O}_{5} \mathrm{t}^{-1}, 20 \mathrm{~g} \mathrm{~K}_{2} \mathrm{O}^{-1}, 59 \mathrm{~g} \mathrm{Ca}^{-1}$, and $40 \mathrm{~g}^{-1}$ were applied into planting hole, using simple super phosphate and potassium chlorate as fertilizer sources. After planting, all treatments were fertigated with mineral fertilizers: urea until 9 months after planting, mono ammonium phosphate from 10 to 15 months after planting, and potassium chlorate from 0 to 15 months after planting, in a rate of $196 \mathrm{~g} \mathrm{~N}, 226 \mathrm{~g} \mathrm{P}_{2} \mathrm{O}_{5}, 81 \mathrm{~g} \mathrm{~K}_{2} \mathrm{O}$, and $127 \mathrm{~g} \mathrm{~S}$. plant ${ }^{-1}$. These rates were determined based on soil chemical analysis and recommendation of fertilizer rates for irrigated guava tree for State of Pernambuco, described by Gonzaga Neto et al. (1998). The treatments tested were: $\mathrm{C}$-control, plants fertigated with mineral fertilizers, as described previously; M- application of $20 \mathrm{~L}$ of manure plant ${ }^{-1}$ before planting; $\mathrm{H}$ - fertigation with $30 \mathrm{Lha}^{-1}$ of Codahumus $20 \mathrm{TM}(10.0 \%$ humic acid w/w, $10.2 \%$ fulvic acid w/w, density $1.37 \mathrm{~g} \mathrm{~cm}^{-3}, \mathrm{pH} 12.0$ ) or $25 \mathrm{~g}$ of humic substances.plant ${ }^{-1}$, according to manufacturer's recommendation; $\mathrm{MH}$ - application of $20 \mathrm{~L}$ of manure.plant ${ }^{-1}$ before planting + fertigation with $25 \mathrm{~g}$ of humic substances.plant ${ }^{-1}$. The experiment was carried out in a totally randomized blocks design, with four treatments and five replications. Each block had five guava trees in $150 \mathrm{~m}^{2}$.

For biochemical analysis, the third pair of leaves of three fertile branches were sampled from three guava trees , totalizing 18 leaves per replication in each treatment, during orchard establishment, on Nov $25^{\text {th }} 2003$, Feb $20^{\text {th }} 2004$, May $18^{\text {th }} 2004$ and Aug $16^{\text {th }} 2004$, which corresponded to 6,9, 12 and 15 months after planting (MAP), respectively. Leaves were grounded in distilled water (1:10, mass: volume) and centrifuged at $2500 \mathrm{xg}$. The supernatant, composed by soluble molecules, was collected for quantification of total soluble sugars (Moris, 1948; Yemm \& Willis 1954), sucrose (Passos, 1996), reducing sugars (Miller, 1959), amino acids (Rosen, 1957) and proteins (Bradford, 1976). The precipitate was used for starch extraction (Allen et al., 1974) and quantification (Moris, 1948; Yemm \& Willis 1954). The leaf contents of these compounds were correlated to weather data during the trial.

\section{RESULTS AND DISCUSSION}

The air temperature, insolation and global solar radiation presented little, but significant, variation among the sampling dates, and lower values were registered in May 2004 (Table 1), due to the cloudy weather that usually occurs during the first semester of the year in Petrolina (Teixeira, 2001).

Protein and amino acid contents had opposite behaviour in relation to either sampling date or treatment (Tables 2 and 3). The higher content of soluble proteins was found in guava trees from treatment M in Feb (9 MAP), May (12 MAP) and Aug 2004 (15 MAP), although on 12 MAP no differences were found between $\mathrm{M}$ and $\mathrm{C}$ (Table 2). The amino acid content in guava tree leaves was higher in plants treated with humic substances $(\mathrm{H})$ in Nov 2003 (6 MAP), but in Feb (9MAP) only plants from M differed from the others treatments. In May (12 MAP) and Aug 2004 (15 MAP) no differences among treatments were observed (Table 3 ).

The higher content of reducing sugars (RS) was observed in Feb 2004 (9 MAP), when the guava trees fertigated only with mineral fertilizers $(C)$ were significantly higher than the other plants and had values around twice the RS content reached in other dates. On the other side, in Aug 2004 (15 MAP), the guava tree plants that presented higher leaf RS content were those from $M$ and $\mathrm{H}$ treatments (Table 4). The guava tree plants treated with humic substances $(\mathrm{H}$ and $\mathrm{MH})$ presented high leaf content of total soluble sugars in Nov 2003 (6 MAP), Feb 2004 (9 MAP), and May 2004 (12 MAP) (Table 5).

Leaf sucrose content of guava tree increased during plant growth with higher values in Aug 2004 (15 MAP), except for the $\mathrm{H}$ treated plants. These plants showed higher leaf sucrose content 
than the others until May 2004 (12 MAP) (Table 6). The guava tree leaf starch content, on the other side, in general, decreased during plant growth. In Feb 2004 (9 MAP), the plants from M had higher leaf starch content than the other treatments (Table 7).

Humic substances may positively influence higher plant metabolism, but more conclusive effects concerning to the effects on plant growth is not possible to have yet due the unknown nature of humic substances (Nardi et al., 2002).

Although there was no visible pattern for the guava tree response to the different treatments, the results indicated that the month with the higher global solar radiation values induced higher protein, total soluble sugars, reducing sugars and starch, and the months with lower air temperatures, insolation and global solar radiation induced high amino acids and sucrose contents (Tables 1 to 7).

The biochemical parameters evaluated presented significant correlation to weather data (Table 8 ). Only guava tree leaf contents of starch and proteins were correlated to all weather data. It seems that global solar radiation has had better correlated with most of the biochemical parameters, with higher correlation coefficients.

Light and air temperature are the major factors that influence the photosynthetic activity in plants, so the starch concentration in leaves is higher in plants exposed to high luminosities and air temperatures (Taiz \& Zeiger, 2002).

Solar radiation influences on photosynthesis and photostimuli processes, and is very important for guava tree growth, flowering and fruit set. Guava tree photosynthesis' rate in response to solar radiation levels is characteristic to $\mathrm{C}_{3}$ plants and its light saturation is very high, $925 \mathrm{mmol} \mathrm{m}^{-1} \mathrm{~s}^{-1}$ of photosynthetic photons flux density - PPFD (Walker et al., 1979). A great solar radiation promotes an increase of sugars and ascorbic acid in guava fruits (Rathore, 1976), while guava trees subjected to low solar radiation intensity present death of branches inside the canopy and low fruit production (Pereira, 1995).

Fruit trees present growth patterns defined according to environmental conditions throughout the year (Wachowicz \& Carvalho, 2002). Tropical species, as guava trees, present continuous and intense growth under ideal weather conditions, which are high air temperature and water availability (Costa \& Pacova, 2003). The low air temperatures induce leaf abscission and growth paralyzation (Wachowicz \& Carvalho, 2002). The ideal air temperature for guava production ranges from $23^{\circ} \mathrm{C}$ to $28^{\circ} \mathrm{C}$, and the optimum annual average air temperature is $25^{\circ} \mathrm{C}$. The photosynthesis and sugar accumulation are also influenced by air temperature, regulating sugar content in the whole plant, as well as total soluble solids, sugars and ascorbic acid in guava fruits (Rathore, 1976).

Other plants showed the same responses to solar radiation and air temperature. Dantas et al. (2005) verified that total soluble, reducing sugars and carbohydrate metabolism enzymes of grapevine leaves were correlated to maximum and average air temperatures and solar radiation, but not to insolation and minimum air temperatures.

Photosynthesis and sugar accumulation in fruit trees are influenced by the sink strength, which means the fruit development stage or the plant phenological phase (Hicklenton et al., 2000; Schrier et al., 2000; Islam \& Khan, 2001). Some of these authors, nevertheless, present simplistic affirmations regarding fruit plant physiology. In those studies, the higher sink strength occurred in the summer, when the air temperature and solar radiation are higher. In field experiments, it is very hard to separate the weather effects from those that are intrinsic to plants, like source-sink relations. 
TABLE 1 - Maximum, average and minimum air temperatures $\left({ }^{\circ} \mathrm{C}\right)$, insolation (hours day ${ }^{-1)}$ and global solar radiation $\left(\mathrm{cal} \mathrm{cm}-1\right.$ day $\left.^{-1}\right)$ at guava leaves leaf sampling dates. Petrolina - PE, Brazil.

Weather data

Maximum air temperature

Average air temperature

Minimum air temperature

Insolation

Global solar radiation

Dates (months after planting - MAP) Nov 252003 (6 MAP) Feb 202004 (9 MAP) May 182004 (12 MAP) Aug 162004 (15 MAP)

\begin{tabular}{rrrc}
35.5 & 31.5 & 29.5 & 31.5 \\
27.9 & 25.6 & 23.0 & 24.8 \\
19.8 & 20.4 & 18.4 & 15.4 \\
9.3 & 9.4 & 4.6 & 10.6 \\
438.1 & 539.4 & 328.6 & 441.9 \\
\hline
\end{tabular}

TABLE 2 - Contents of soluble proteins ( $\mathrm{mg} \mathrm{g}^{-1}$ of fresh matter) in guava tree leaves during orchard establishment. Petrolina - PE, Brazil.

\begin{tabular}{lcccc}
\hline \multirow{2}{*}{ Treatments } & \multicolumn{4}{c}{ Dates (months after planting - MAP) } \\
& Nov 25 2003 (6 MAP) & Feb 20 2004 (9 MAP) & May 18 2004 (12 MAP) & Aug 16 2004 (15 MAP) \\
\hline $\mathrm{C}^{(1)}$ & $4.152 \mathrm{cA}^{(2)}$ & $6.369 \mathrm{aB}$ & $5.391 \mathrm{bA}$ & $6.036 \mathrm{aB}$ \\
$\mathrm{M}$ & $4.441 \mathrm{cA}$ & $7.097 \mathrm{aA}$ & $5.669 \mathrm{bA}$ & $6.702 \mathrm{aA}$ \\
$\mathrm{H}$ & $4.552 \mathrm{bA}$ & $5.952 \mathrm{aB}$ & $4.763 \mathrm{bB}$ & $6.102 \mathrm{aB}$ \\
$\mathrm{MH}$ & $4.608 \mathrm{bA}$ & $5.891 \mathrm{aB}$ & $4.441 \mathrm{bB}$ & $6.119 \mathrm{aB}$ \\
\hline
\end{tabular}

$\mathrm{CV}=4.40 \%$

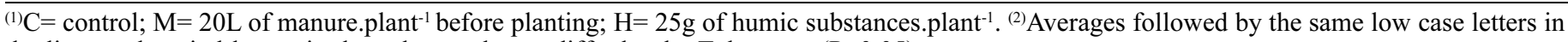
the lines and capital letters in the columns do not differ by the Tukey test $(\mathrm{P}>0.05)$.

TABLE 3 - Contents of amino acids ( $\mathrm{mg} \mathrm{g}^{-1}$ of fresh matter) in guava tree leaves during orchard establishment.Petrolina - PE, Brazil.

\begin{tabular}{lcccc}
\hline \multirow{2}{*}{ Treatments } & \multicolumn{4}{c}{ Dates (months after planting - MAP) } \\
& Nov 25 2003 (6 MAP) & Feb 20 2004 (9 MAP) & May 18 2004 (12 MAP) & Aug 16 2004 (15 MAP) \\
\hline $\mathrm{C}^{(1)}$ & $7.991 \mathrm{aB}^{(2)}$ & $5.456 \mathrm{bAB}$ & $7.114 \mathrm{abA}$ & $6.362 \mathrm{abA}$ \\
$\mathrm{M}$ & $6.680 \mathrm{aB}$ & $4.106 \mathrm{bB}$ & $7.981 \mathrm{aA}$ & $7.470 \mathrm{aA}$ \\
$\mathrm{H}$ & $9.822 \mathrm{aA}$ & $5.321 \mathrm{bAB}$ & $6.603 \mathrm{bA}$ & $5.890 \mathrm{bA}$ \\
$\mathrm{MH}$ & $7.509 \mathrm{abB}$ & $6.130 \mathrm{bA}$ & $8.241 \mathrm{aA}$ & $7.335 \mathrm{abA}$ \\
\hline
\end{tabular}

$\mathrm{CV}=11.33 \%$

${ }^{(1)} \mathrm{C}=$ control; $\mathrm{M}=20 \mathrm{~L}$ of manure.plant ${ }^{-1}$ before planting; $\mathrm{H}=25 \mathrm{~g}$ of humic substances.plant $\mathrm{t}^{-1} .{ }^{(2)}$ Averages followed by the same low case letters in the lines and capital letters in the columns do not differ by the Tukey test $(\mathrm{P}>0.05)$.

TABLE 4 - Contents of reducing sugars ( $\mu \mathrm{mol} \mathrm{g}{ }^{-1}$ of fresh matter) in guava tree leaves during orchard establishment. Petrolina - PE, Brazil.

\begin{tabular}{lcccc}
\hline \multirow{2}{*}{ Treatments } & \multicolumn{4}{c}{ Dates (months after planting - MAP) } \\
\cline { 2 - 5 } $\mathrm{C}^{(1)}$ & Nov 25 2003 (6 MAP) & Feb 20 2004 (9 MAP) & May 18 2004 (12 MAP) & Aug 16 2004 (15 MAP) \\
\cline { 2 - 5 } $\mathrm{M}$ & $47.800 \mathrm{bAB}^{(2)}$ & $92.195 \mathrm{aA}$ & $53.345 \mathrm{bA}$ & $54.522 \mathrm{bB}$ \\
$\mathrm{H}$ & $42.812 \mathrm{cB}$ & $79.586 \mathrm{aB}$ & $57.497 \mathrm{bA}$ & $73.049 \mathrm{aA}$ \\
$\mathrm{MH}$ & $55.700 \mathrm{cA}$ & $74.505 \mathrm{aBC}$ & $57.651 \mathrm{bcA}$ & $67.627 \mathrm{abA}$ \\
\hline
\end{tabular}

$\mathrm{CV}=7.62 \%$

${ }^{(1)} \mathrm{C}=$ control; $\mathrm{M}=20 \mathrm{~L}$ of manure.plant ${ }^{-1}$ before planting; $\mathrm{H}=25 \mathrm{~g}$ of humic substances.plant $\mathrm{t}^{-1} .{ }^{(2)}$ Averages followed by the same low case letters in the lines and capital letters in the columns do not differ by the Tukey test $(\mathrm{P}>0.05)$. 
TABLE 5 - Contents of total soluble sugars ( $\mu \mathrm{g} \mathrm{g}^{-1}$ of fresh matter) in guava tree leaves during orchard establishment. Petrolina - PE, Brazil.

\begin{tabular}{lcccc}
\hline \multirow{2}{*}{ Treatments } & \multicolumn{4}{c}{ Dates (months after planting - MAP) } \\
$\mathrm{C}^{(1)}$ & Nov 25, 2003 (6 MAP) & Feb 20, 2004 (9 MAP) & May 18, 2004 (12 MAP) & Aug 16, 2004 (15 MAP) \\
\cline { 2 - 5 } $\mathrm{M}$ & $17.242 \mathrm{bB}^{(2)}$ & $21.518 \mathrm{aC}$ & $18.521 \mathrm{bA}$ & $20.508 \mathrm{aA}$ \\
$\mathrm{H}$ & $10.609 \mathrm{bC}$ & $18.993 \mathrm{aC}$ & $20.373 \mathrm{aA}$ & $20.306 \mathrm{aAB}$ \\
$\mathrm{MH}$ & $20.070 \mathrm{aA}$ & $15.794 \mathrm{bB}$ & $16.434 \mathrm{bB}$ & $18.589 \mathrm{aC}$ \\
& $16.367 \mathrm{cB}$ & $16.703 \mathrm{bcA}$ & $18.522 \mathrm{abA}$ & $19.296 \mathrm{aBC}$ \\
\hline
\end{tabular}

$\mathrm{CV}=4.69 \%$

${ }^{(1)} \mathrm{C}=$ control; $\mathrm{M}=20 \mathrm{~L}$ of manure.plant $\mathrm{t}^{-1}$ before planting; $\mathrm{H}=25 \mathrm{~g}$ of humic substances.plant $\mathrm{t}^{-1}$. ${ }^{(2)}$ Averages followed by the same low case letters in the lines and capital letters in the columns do not differ by the Tukey test $(\mathrm{P}>0.05)$.

TABLE 6 - Contents of sucrose ( $\mu \mathrm{g} \mathrm{g}^{-1}$ of fresh matter) in guava tree leaves during orchard establishment. Petrolina - PE, Brazil.

\begin{tabular}{lcccc}
\hline \multirow{2}{*}{ Treatments } & \multicolumn{4}{c}{ Dates (months after planting - MAP) } \\
$\mathrm{C}^{(1)}$ & Nov 25 2003 (6 MAP) & Feb 20 2004 (9 MAP) & May 18 2004 (12 MAP) & Aug 16 2004 (15 MAP) \\
\cline { 2 - 5 } $\mathrm{M}$ & $39.364 \mathrm{bA}^{(2)}$ & $29.273 \mathrm{cA}$ & $32.334 \mathrm{cC}$ & $50.842 \mathrm{aB}$ \\
$\mathrm{H}$ & $30.325 \mathrm{cB}$ & $31.282 \mathrm{cA}$ & $39.890 \mathrm{bB}$ & $49.072 \mathrm{aB}$ \\
$\mathrm{MH}$ & $44.481 \mathrm{aA}$ & $34.247 \mathrm{bA}$ & $49.312 \mathrm{aA}$ & $34.438 \mathrm{bC}$ \\
\hline
\end{tabular}

$\mathrm{CV}=7.25 \%$

${ }^{(1)} \mathrm{C}=$ control; $\mathrm{M}=20 \mathrm{~L}$ of manure.plant ${ }^{-1}$ before planting; $\mathrm{H}=25 \mathrm{~g}$ of humic substances.plant ${ }^{-1} .^{(2)}$ Averages followed by the same low case letters in the lines and capital letters in the columns do not differ by the Tukey test $(\mathrm{P}>0.05)$.

TABLE 7 - Contents of starch ( $\mathrm{mol} \mathrm{g}^{-1}$ of fresh matter) in guava tree leaves during orchard establishment Petrolina - PE, Brazil.

\begin{tabular}{|c|c|c|c|c|c|}
\hline \multirow{2}{*}{ Treatments } & \multicolumn{5}{|c|}{ Date (months after planting - MAP) } \\
\hline & Nov 252003 (6 MAP) & Feb 202004 (9 MAP) & \multicolumn{2}{|c|}{ May 182004 (12 MAP) } & Aug 162004 (15 MAP) \\
\hline $\mathrm{C}^{(1)}$ & $2.864 \mathrm{abA}^{(2)}$ & $3.031 \mathrm{aB}$ & $1.442 \mathrm{cA}$ & & $2.147 \mathrm{bcA}$ \\
\hline $\mathrm{M}$ & $2.925 \mathrm{bA}$ & $3.870 \mathrm{aA}$ & $1.531 \mathrm{cA}$ & & $2.153 \mathrm{cA}$ \\
\hline $\mathrm{H}$ & $2.475 \mathrm{aA}$ & $2.386 \mathrm{aBC}$ & $1.959 \mathrm{aA}$ & & $2.347 \mathrm{aA}$ \\
\hline $\mathrm{MH}$ & $2.675 \mathrm{aA}$ & $1.992 \mathrm{abC}$ & $1.586 \mathrm{bA}$ & & $2.270 \mathrm{abA}$ \\
\hline \multicolumn{6}{|l|}{$\mathrm{CV}=14.34 \%$} \\
\hline \multirow{2}{*}{\multicolumn{6}{|c|}{$\begin{array}{l}\begin{array}{l}\text { (1)(1) } \mathrm{C}=\text { control; } \mathrm{M}=20 \mathrm{~L} \text { of manure.plant }{ }^{-1} \text { before planting; } \mathrm{H}=25 \mathrm{~g} \text { of humic substances.plant }{ }^{-1} \cdot{ }^{(2)} \text { Averages followed by the same low case letters } \\
\text { in the lines and capital letters in the columns do not differ by the Tukey test }(\mathrm{P}>0.05) .\end{array} \\
\text { TABLE } 8 \text { - Correlation coefficients among weather data and biochemical data and weather and biochemical data from parameters from } \\
\text { guava tree leaves, during orchard establishment. Petrolina - PE, Brazil. }\end{array}$}} \\
\hline & & & & & \\
\hline & $\begin{array}{c}\text { Maximum } \\
\text { air temperature }\end{array}$ & $\begin{array}{c}\text { Average } \\
\text { air temperature }\end{array}$ & $\begin{array}{c}\text { Minimum } \\
\text { air temperature }\end{array}$ & Insolation & $\begin{array}{c}\text { Global } \\
\text { solar radiation }\end{array}$ \\
\hline Proteins & $-0.433 * *$ & $-0.296^{*}$ & $-0.294 *$ & $0.378 * *$ & $0.497 * *$ \\
\hline Amino acids & $0.256^{\mathrm{ns}}$ & $0.106^{\mathrm{ns}}$ & $-0.118^{\mathrm{ns}}$ & $-0.235^{\mathrm{ns}}$ & $-0.528 * *$ \\
\hline Reducing sugars & $-0.318 *$ & $-0.143^{\mathrm{ns}}$ & $0.130^{\mathrm{ns}}$ & $0.261^{\mathrm{ns}}$ & $0.605 * *$ \\
\hline Total soluble sugars & $-0.385^{* *}$ & $-0.368 *$ & $-0.356^{*}$ & $0.0168^{\mathrm{ns}}$ & $-0.0231^{\mathrm{ns}}$ \\
\hline Starch & $0.510^{* *}$ & $0.608 * *$ & $0.356^{*}$ & $0.536^{* *}$ & $0.632 * *$ \\
\hline Sucrose & $-0.00264^{\mathrm{ns}}$ & $-0.0958^{\mathrm{ns}}$ & $-0.630 * *$ & $0.191^{\mathrm{ns}}$ & $-0.237^{\mathrm{ns}}$ \\
\hline
\end{tabular}

** highly significant correlation $(\mathrm{P}<0,01)$; * significant correlation $(\mathrm{P}<0,05)$; ${ }^{\text {ns }}$ non significant correlation $(\mathrm{P}>0,05)$ 


\section{CONCLUSIONS}

During the guava tree orchard establishment, the fertigation treatments and the plant age did not present conclusive effects on guava leaf content of carbohydrates, proteins and amino acids. On the other hand, these contents were influenced by the weather, specifically to data that relies on sun energy (air temperature and global radiation), because of their effects on plant photosynthesis.

\section{REFERENCES}

ALLEN, S. E.; GRIMSHAW, H. M.; PARKINSON, J. A.; QUARMBY, C. Chemical analysis of ecological materials. Oxford: Blackwell Scientific, 1974.

ANDRADE; F. V.; MENDONÇA, E. S.; SILVA. I. R.; MATEUS, R. F. Low molecular weight and humic acids increase phosphorus uptake and corn growth in Oxisoils. In: HUMIC SUBSTANCES AND SOIL AND WATER ENVIRONMENT, 2004, São Pedro, Proceedings... São Pedro: Embrapa Instrumentação, 2004. p.211214.

AYUSO, M.; HÉRNANDEZ, T.; GARCIA, C.; PASCUAL, J.A. Stimulation of barley growth and nutrient absorption by humic substances originating from various organic materials. Bioresource Technology, Kidlington, v.57, n.3, p.251-257, 1996.

BRADFORD, M. M. A rapid and sensitive method for the quantitatification of microgram quantities of protein utilizing the principle of protein-dye binding. Analytical Biochemistry. San Diego, v.72, p.248-254, 1976.

BASSOI, L. H.; SILVA, S. T.; SILVAFILHO, A. V. Efeito da aplicação de ácidos orgânicos na produção de uva cv. Itália no Vale do São Francisco. In: ENCONTRO BRASILEIRO DE SUBSTÂNCIAS HÚMICAS, 6., 2005, Rio de Janeiro. Anais... Rio de Janeiro: Embrapa Solos, 2005. p.1-3.

CALIMA, D. F.; PANETO, R. O.; AGUILAR, M. A. G.; FOLLI, F. B.; SOUZA, C. A. S.; SONEGHETI, S. Crescimento e fotossíntese de clones de cacau (Theobroma cacao L.) com resistência diferencial a Verticillium dahliae submetidos diferentes doses de Turfa Líquida ${ }^{\circledR}$. In: ENCONTRO BRASILEIRO DE SUBSTÂNCIAS HÚMICAS, 6., 2005, Rio de Janeiro. Anais... Rio de Janeiro: Embrapa Solos, 2005. p.9-11.

CHEN,Y; AVIAD, T. Effects of humic substances on plant growth. In: MACCARTHY, P.; CLAPP, E. E.; MALCOLM, R. L.; BLOOM, P. R. (Ed.) (eds.) Humic substances in soil and crop sciences: selected readings.
COSTA, A. F. S.; PACOVA, B. E. V. Botânica e variedades. In: COSTA, A. F. S.; COSTA, A. N. (Ed.) Tecnologias para produção de goiaba. Vitória: Incaper, 2003. p.27-56.

EYHERAGUIBEL, B.; SILVESTRE, J.; MORARD, P. Physiological effects of humic like substances on maize. In: HUMIC SUBSTANCES AND SOILAND WATER ENVIRONMENT, 2004, São Pedro. Proceedings... São Pedro: Embrapa Instrumentação, 2004. p.200-202.

FERNÁNDEZ-ESCOBAR, R.; BENLLOCH, M.; BARRANCO, D.; DUENAS, D.; GANÁN, J. A. G. Response of olive trees to foliar appliaction of humic substances extracted from leonardite. Scientia Horticulturae, Amsterdan, v.66, n.3-4, p. 191-200, 1996.

SILVA, D. J.; PEREIRA, J.R. Recomendações de calcário e fertilizantes. In: CAVALCANTI, F.J.A. (Ed.) Recomendações de adubação para o estado de Pernambuco ( $2^{\mathrm{a}}$ aproximação). Recife: IPA, 1998. p.147GONZAGANETO, L.;

J. E. F.; PEDROSA, A. C.; DANTAS, A . P.; SILVA, H. M. Comportamento produtivo da goiabeira sob irrigação no vale do rio Moxotó. I. Variedades industriais: onze anos de produção. Revista Brasileira de Fruticultura, Cruz das Almas, v. 13, n. 3, p. 103-114, 1991.

HICKLENTON, P. R.; REEKIE, J. Y.; GORDON, R. J.; PERCIVAL, D. C. Seasonal patterns of photosynthesis and stomatal conductance in lowbush blueberry plants managed in a two-year production cycle. Hortscience, Alexandria, v.35, n.1, p.55-59. 2000.

ISLAM, M. D. S.; KHAN, S. Seasonal fluctuations of carbohydrate accumulation and metabolism of three tomatoes (Lycopersicon esculentum Mill.) cultivars grown at seven sowing times. Journal of Horticultural Science \& Biotechnology, Ashford, v.76, n.6, p.764-770, 2001

KONONOVA, M. M. Materia orgánica del suelo: su naturaleza, propriedades y métodos de investigación. Barcelona: Oikos-Tau, 1982.364p.

MAGGIONI, A.; VARANINI, Z;; NARDI, S. Action of soil humic matter on plant roots: stimulation of ion uptake and effects on $(\mathrm{Mg} 2++\mathrm{K}+)$ ATPase activity. Science of the Total Environment, Madison, v.62, p.355-363, 1987.

MILLER, G.L. Use of dinitrosalicylis acid reagent for determination of reducing sugars. Analytical Chemistry, Washington, v.31, n.1, p.426-428, 1959. 
MORIS, D. L. Quantitative determiantion of carbohydrates with Drywood's anthrone reagent. Science, Washington, v.107, p.254255,1948 .

MURILLO, J.M.; MADEJÓN, E.; MADEJÓN, P.; CABRERA, F. The response of wild olive to the addition of a fulvic-rich acid amendement to soils pollueted by trace elements. Journal of Arid Environments, London, v.63, p.284-303, 2005.

NARDI, S.; PIZZEGHELLO, D.; MUSCOLO, A.; VIANELLO, A. Physiological effects of humic substances in plant growth. Soil Biology and Biochemistry, Exeter, v.34, n.11, p.1527-1536, 2002.

PASSOS, L. P. Métodos analíticos e laboratoriais em fisiologia vegetal. Coronel Pacheco: Embrapa Gado de Leite, 1996. 223p.

PEREIRA, J.R.; MÉNDEZ, J. Inibition of peroxidase by algal humic and fulvic acids. Biologic Plants, Prague, v.1, p.171-182, 1976. PEREIRA, F. M. Cultura da goiabeira. São Paulo: UNESP/FUNEP, 1995.30p.

PETROVIC, P., VITOROVIC, D., JABLANOVIC, M. Investigations of biological effects of humic acids. Acta Biological Medical Experimental, Budapest, v.7, p.21-25, 1982.

PINTON, R., VARANINI, Z., VIZZOTTO, G. Soil humic substances affect transport properties of tonoplast vesicles isoated from oat roots. Plant and Soil, The Hague, v.42, p.203-210, 1992.

POSPÍSIL, F.; HRUBCOVA, M. The effect of humic acids and their fractions on the phytase activity. Vedecke Prace Vyskumneho Ustavu Rastlinnej Vyroby, Praze-Ruzini, v.18, p.47-54, 1974.

RATHORE, D. S. Effect of season in the growth and chemical composition of guava (Pisidium guajava L.). Journal of Horticultural Science, Ashford, v. 51, n.1, p.41-47, 1976.

ROSA, C. M.; CASTILHOS, R. M. V.; VAHL, L. C.; COSTA, P. F. P. Effect of fulvic acids on plant growth, root morphology and macronutrient uptake by oats. In: HUMIC SUBSTANCES AND SOIL AND WATER ENVIRONMENT, 2004, São Pedro, Proceedings... São Pedro: Embrapa Instrumentação, 2004. p. 207210.

ROSEN, H. A modified ninhydrin colorimetric analysis for amino acids. Archives of Biochemistry and Biophysics, San Diego, v.67, p.10-15, 1957.

SAMSON, G., VISSER, S.A. Surface-active effect of humic acids on potato cell membrane properties. Soil Biology Biochemistry, Bern, v.21, p.343-347, 1989.

SCHRIER, A. A.; HOFFMANN-THOMA, G.; BEL, A. J. Temperature effects on symplasmic and apoplasmic phloem loading and loading-associated carbohydrate processing. Australian Journal of Plant Physiology, Collingwood, v.27, p.769778,2000 .
TAIZ, L. ; ZEIGER, E. Plant physiology. New York: Benjamin Cummings, 2002.565p.

TEIXEIRA, A. H. C. Informações agrgometeorológicas do pólo Petrolina-PE/ Juazeiro-BA. Petrolina: Embrapa Semi-Árido, 2001. $46 \mathrm{p}$.

VAUGHAN, D. ; ORD, B.G. An effect of soil organic matter on invertase activity in soil. Soil Biology Biochemistry, Bern, v.12, p.449-450, 1980.

WACHOWICZ, C. M.; CARVALHO, R. I. N. Fisiologia vegetal: produção e pós colheita. Curitiba: Champanhat, 2002.424p.

WALKER, R. R.; KRIEDEMANN, P. E.; MAGGS, D. H. Growth, leaf physiology and fruit development of salt stressed guavas. Australian Journal of Agricultural Research. Collingwood, v.30, p.477, 1979 .

YEMM, E. W. ; WILLIS, A. J. The estimation of carbohydrates in plants extracts by anthrone. Biochemical Journal, Colchester, v. 57, p.508-514, 1954. 